\title{
Evaluation of Polymer Electrolyte Membrane Fuel Cells by Electrochemical Impedance Spectroscopy under Different Operation
}

\section{Conditions and Corrosion}

Masanobu Kumagai ${ }^{a}$, Seung-Taek Myung ${ }^{b} *$, Takuma Ichikawa ${ }^{b}$ and Hitoshi Yashiro $^{\text {b }}$

${ }^{a}$ Taiyo Stainless Spring Co., Ltd., 2-8-6 Shakujiicho, Nerimaku, Tokyo 177-0041, Japan

${ }^{b}$ Department of Chemical Engineering, Iwate University, 4-3-5 Ueda, Morioka, Iwate 020-8551, Japan

\begin{abstract}
\footnotetext{
*Corresponding author Tel/Fax: +81 196216345

E-mail: smyung @iwate-u.ac.jp (S.-T. Myung)

Tel/Fax: +81196216330

E-mail: yashiro@iwate-u.ac.jp (H. Yashiro)
}

Electrochemical impedance spectroscopy (EIS) was employed for in situ diagnosis for polymer electrolyte membrane fuel cells during operation. First, EIS was measured as a function of operation parameters such as applied current density, gas flow rates and gas humidification temperature. The resistance that correlated with conductivity of the membrane and the contact resistance between bipolar plate and gas 
diffusion layer (GDL) was set as $R_{\mathrm{m}}$ in the assumed equivalent circuit. The charge transfer resistances were considered for cathode $\left(R_{\mathrm{ct}}(\mathrm{C})\right)$. The value of $R_{\mathrm{ct}}(\mathrm{C})$ was sensitive to the parameters that affected cell voltage. Additionally, the diffusion resistance $\left(R_{\mathrm{d}}\right)$ was ascribed to the effect of oxygen supply and drainage of generated water. Second, the influence of corrosion of type 430 stainless steel bipolar plates was evaluated by EIS method during operation. Corrosion of the stainless steel bipolar plates resulted in an increase in the value of $R_{\mathrm{d}}$.

Keyword; Electrochemical impedance spectroscopy; Corrosion; Bipolar plates; PEMFC

\section{Introduction}

Polymer electrolyte membrane fuel cells (PEMFC) are being expected as a clean power generation system for wide applications. For the best performance of PEMFC, it is necessary to optimize the operating conditions of the cells. The performance of PEMFC is usually evaluated by electrochemical techniques, such as current-voltage measurement, cyclic voltammetry, electrochemical impedance spectroscopy (EIS), and current interrupt methods. Among them, EIS is considered as one of the most powerful techniques, since it can distinguish kinetically different 
reaction processes. Yuan et al. [1] reported EIS has already become a primary tool in PEMFC research. EIS method is also used effectively for analyses of the amount of catalysts [2-5], nafion content [3,6-8], membrane thickness [9,10], GDL structure [11-19], proton conductivity [20-26], humidification condition [3,9,27-30] and stack [24,31-36]. For example, Paganin et al. [2] and Song et al. [3] suggested that charge transfer resistance is much smaller with increasing amount of catalysts. Freire et al. [9] worked on the influence of membrane thickness and humidification conditions by the EIS method and reported that nafion membrane $(117,115,1135$ and 112) and their thickness (average size of 175, 125, 80 and $50 \mu \mathrm{m}$ ) influence charge transfer resistance and mass transfer resistance. In addition, the low-frequency region is due mainly to the flooding of the cathode side. Yan et al. [35] investigated impedance behavior of a $2 \mathrm{~kW}$ stack under different operating conditions. They suggested the humidification of air and temperature mainly influence the charge transfer resistance and flow rate of air is related to the mass transfer resistance.

As for bipolar plates, metallic materials especially stainless steels are under intensive examination as a promising alternative to carbon composites. Cho et al [37] reported that mechanical strength and cost of the carbon composite plates are necessary to be improved. Thus, stainless steels have attracted wide attention to substitute the 
carbonaceous bipolar plates [38-44]. However, stainless steels could be readily corroded in the PEMFC environment because the $\mathrm{SO}_{4}{ }^{2-}$ and $\mathrm{F}^{-}$anions released from the membrane polymer in the course of cell operation, leading to low $\mathrm{pH}$. Consequently, the corrosion induces higher contact resistance between gas diffusion layer (GDL) and bipolar plates. In addition, $\mathrm{Fe}^{2+}, \mathrm{Ni}^{2+}$ and $\mathrm{Cr}^{3+}$ released from the corroded stainless steel bipolar plates are also immobilized in the membrane, affecting detrimentally to cell performance [40,45-47]. Thus, application of EIS to PEMFC with metallic bipolar plates is necessary to establish a procedure for diagnosis of cell performance, as reported by Ishibashi et al. [48]. To the best of our knowledge, no information is available on the application of EIS focusing on corrosion of stainless steel bipolar plates in the PEMFC environment.

In the present study, EIS measurements were performed to confirm the relation between EIS parameters and operation factors that can affect the fuel cell performance using type 430 stainless steel bipolar plates to investigate the phenomena in comparison with graphite bipolar plates when corrosion takes place. Therefore, these bipolar plates employing single cells were operated to understand the corrosion of bipolar plates by means of EIS analysis. 


\section{Experimental}

Specimen preparation.- Plates of graphite and type 430 stainless steel (80

$\mathrm{mm} \times 80 \mathrm{~mm} \times 6 \mathrm{~mm}$ ) were machined into bipolar plates with a serpentine flow field according to the NEDO report by JARI [49]. The chemical composition of the type 430 stainless steel is described in Table 1 . The electrode area was $50 \mathrm{~mm} \times 50 \mathrm{~mm}$. The stainless steel surface was polished with a diamond paste polisher of $6 \mu \mathrm{m}$ and cleaned ultrasonically in hexane for $15 \mathrm{~min}$. No further pretreatment was made for the bipolar plates.

Single cell operation. - A single cell was assembled from bipolar plates (graphite or type 430 stainless steel) and a commercially available MEA employing carbon paper GDL with compressive force of $150 \mathrm{~N} \mathrm{~cm}^{-2}$. The typical operation condition, unless otherwise stated, was as follows: cell temperature of $348 \mathrm{~K}$, humidification temperature for reactant gases of $343 \mathrm{~K}$, hydrogen flow rate of 0.124 normal liter per minute (NLPM, $70 \%$ utilization at $0.5 \mathrm{~A} \mathrm{~cm}^{-2}$ ), air flow rate of 0.520 NLPM (40\% utilization of $\mathrm{O}_{2}$ at $0.5 \mathrm{~A} \mathrm{~cm}^{-2}$ ) and applied current density of $0.5 \mathrm{~A} \mathrm{~cm}^{-2}$. EIS data were collected in the frequency range from $15 \mathrm{kHz}$ to $0.1 \mathrm{~Hz}$ with an applied amplitude of $4 \mathrm{~mA} \mathrm{~cm}$ c $^{-2}$ (FC-200FA, CHINO) during cell operations. X-ray fluorescence (XRF, Philips Magix PRO-S) was employed to quantify the MEA 
contamination.

\section{Results and discussion}

Selection of an equivalent circuit - Figure 1 shows the assumed equivalent circuit. The equivalent circuit presented in Fig. 1 is referred from the literature by Yan et al. [33,35] and Wagner et al. [49]. In addition, the conventional double-layer capacitance is replaced by a constant phase element (CPE), based on Ciureaun's report [51]. The $R_{\mathrm{m}}$ represents the sum of resistive elements present in series such as electrolyte (membrane) resistance. The $R_{\mathrm{ct}}(\mathrm{C})$ describes charge transfer resistances for cathode, which is related to semicircles from high to medium frequency. The $R_{\mathrm{d}}$ corresponds to diffusion resistance from the medium to low frequency which is affected by oxygen supply and drainage of generated water. The resistance stemming from the anode side $R_{\mathrm{d}}(\mathrm{A})$ was excluded from the equivalent circuit due to its negligible size, compared with that in the cathode side. It should be stated $R_{\mathrm{ct}}(\mathrm{A})<R_{\mathrm{ct}}(\mathrm{C})$ because the reaction rate of oxygen reduction is usually slower than that of hydrogen oxidation $[36,52]$. It is found that the observed impedance spectrum fits well with the calculated one.

Influence of current density - Figure 2 shows the initial $i$ - $V$ characteristic 
(Fig.2a), the impedance behavior (Fig.2b) and relationship between the applied current density and the calculated resistance components (Fig.2c) from the equivalent circuit for the graphite and type 430 stainless steel bipolar plates employing single cells. As can be seen from Fig.2a, the initial cell voltage was approximately $0.97 \mathrm{~V}$ for the graphite bipolar plates employing cell and $0.96 \mathrm{~V}$ for the type 430 stainless steel ones at an open circuit state and it reached around $0.67 \mathrm{~V}$ for the graphite bipolar plates employing cell and $0.62 \mathrm{~V}$ for the type 430 stainless steel one at $0.5 \mathrm{~A} \mathrm{~cm}^{-2}$. Cole-Cole plots for both cells are composed of two semicircles, and the size of the main semicircle becomes smaller with increasing current density (Fig. 2b). Additional arc appeared in the low frequency when the current densities were higher than $0.3 \mathrm{~A} \mathrm{~cm}^{-2}$. The results are summarized in Fig. 2c. Basically, both cells exhibit the similar impedance behavior when the applied current densities vary. Major difference that we found is the $R_{\mathrm{m}}$ parameter. Graphite bipolar plate employing cell exhibited the small and constant $R_{\mathrm{m}}$ value approximating to $88 \mathrm{~m} \Omega \mathrm{cm}^{2}$. On the contrary, the $R_{\mathrm{m}}$ for the type 430 bipolar plate employing cell appeared to be close to $250 \mathrm{~m} \Omega \mathrm{cm}^{2}$ at $\mathrm{OCV}$ and $208 \mathrm{~m} \Omega \mathrm{cm}^{2}$ at $0.5 \mathrm{~A} \mathrm{~cm}^{-2}$. The variation of the $R_{\mathrm{m}}$ seems to be related to the operation voltage. As we previously reported $[43-45,53]$, the difference in the operation voltage results from the difference in the interfacial contact resistance (ICR) between bipolar plate and GDL. 
That is, the lower the ICR, the higher the operation voltage. So that the lower ICR values for the graphite cell affects the lower impedance $\left(R_{\mathrm{m}}\right)$ with higher operation voltage. With increasing current density, the value of $R_{\mathrm{ct}}(\mathrm{C})$ decreased considerably. The value of $R_{\mathrm{ct}}(\mathrm{C})$ was approximately $453 \mathrm{~m} \Omega \mathrm{cm}^{2}$ for graphite bipolar plate employing cell and $455 \mathrm{~m} \Omega \mathrm{cm}^{2}$ for type 430 stainless steel one at $0.1 \mathrm{~A} \mathrm{~cm}^{-2}$ and it reached around $213 \mathrm{~m} \Omega \mathrm{cm}^{2}$ for graphite bipolar plate employing cell and $165 \mathrm{~m} \Omega \mathrm{cm}^{2}$ for type 430 stainless steel one at $0.5 \mathrm{~A} \mathrm{~cm}^{-2}$. On the other hand, the value of $R_{\mathrm{d}}$ increased gradually with increasing current density. The value of $R_{\mathrm{d}}$ for both cells was approximately $35 \mathrm{~m} \Omega$ $\mathrm{cm}^{2}$ at $0.1 \mathrm{~A} \mathrm{~cm}^{-2}$ and it reached around $110 \mathrm{~m} \Omega \mathrm{cm}^{2}$ at $0.5 \mathrm{~A} \mathrm{~cm}^{-2}$. This is probably because of the obstruction in supply of oxygen to the electrode surface or in drainage of the generated water from the GDL at cathode side.

Influence of hydrogen flow rate - Effect of flow rate of hydrogen or air on the cell performance was evaluated by the EIS method. Figure 3a shows the cell voltages for graphite and type 430 stainless steel bipolar plates as a function of hydrogen flow rate. Note that both cells showed the highest voltage at a hydrogen flow rate of 0.124 NLPM by applying a constant current of $0.5 \mathrm{~A} \mathrm{~cm}^{-2}$, after which the cell voltages were almost constant regardless of the hydrogen flow rate. Figure $3 \mathrm{~b}$ exhibits the resulting impedance spectra measured along with variation of hydrogen flow rate. The smaller 
ICR also led to the smaller impedance $\left(R_{\mathrm{m}}\right)$ for the graphite cell. It is clear that the impedance spectra are independent on the variation of the hydrogen flow rate for both cells. Figure 3c shows the corresponding calculated resistance parameters from Fig.3b, based on the equivalent circuit. Similar to the voltage variation shown in Fig. 3a, no significant changes in $R_{\mathrm{m}}, R_{\mathrm{ct}}(\mathrm{C})$ and $R_{\mathrm{d}}$ are observed with increasing the flow rate of hydrogen, indicating that hydrogen flow rate does not seriously affect the cell performance within the variation range evaluated here.

Influence of air flow rate - Figure 4a shows the measured cell voltages for graphite and type 430 stainless steel bipolar plates employing cells as a function of air flow rate. The cell voltages became higher with increasing air flow rate. Cell voltage approximated to $0.66 \mathrm{~V}$ for graphite bipolar plate employing cell and $0.61 \mathrm{~V}$ for type 430 stainless steel one at 0.35 NLPM, which corresponds to $70 \%$ of the utilization of air. The voltage approximated to $0.71 \mathrm{~V}$ for graphite and $0.65 \mathrm{~V}$ for the type 430 stainless steel at 2.08 NLPM (10\% of utilization). Obviously, the increased amount of oxygen supply led to higher operation voltage. However, this is not always preferred because too fast flowing of oxygen could cause damage to membrane and oxygen leakage during cell operations. Figure $4 \mathrm{~b}$ shows the impedance spectra measured under different air flow rates. The size of the arc appeared in the low frequency tends to 
become smaller with increasing the air flow rate. This would be because the oxygen concentration at the electrode surface becomes higher and drainage of formed water from the electrode surface and GDL is facilitated by the fast air flowing. Figure 4c shows the calculated values of resistive elements from the equivalent circuit as a function of air flow rate. With increasing the air flow rate, the values of the $R_{\mathrm{ct}}(\mathrm{C})$ and the $R_{\mathrm{d}}$ decreased considerably. The $R_{\mathrm{ct}}(\mathrm{C})$ was approximately $230 \mathrm{~m} \Omega \mathrm{cm}^{2}$ for graphite bipolar plate employing cell and $205 \mathrm{~m} \Omega \mathrm{cm}^{2}$ for type 430 stainless steel one at 0.35 NLPM and it reached around $100 \mathrm{~m} \Omega \mathrm{cm}^{2}$ for graphite bipolar plate employing cell and $145 \mathrm{~m} \Omega \mathrm{cm}^{2}$ for type 430 stainless steel one at 2.08 NLPM. It is likely that the value of $R_{\mathrm{ct}}(\mathrm{C})$ is correlative with cell voltage and air flow rate. In addition, the value of $R_{\mathrm{d}}$ was approximately $263 \mathrm{~m} \Omega \mathrm{cm}^{2}$ for graphite bipolar plate employing cell and $145 \mathrm{~m} \Omega \mathrm{cm}^{2}$ for type 430 stainless steel one at 0.35 NLPM and it reached around $43 \mathrm{~m} \Omega \mathrm{cm}^{2}$ for graphite bipolar plate employing cell and $15 \mathrm{~m} \Omega \mathrm{cm}^{2}$ for type 430 stainless steel one at 2.08 NLPM. On the other hand, the value of the $R_{\mathrm{m}}$ is slightly increased from 0.35 NLPM to 2.08 NLPM. Thus, the arc appeared in the low frequency should be attributed to diffusion resistance in the cathode side. As mentioned above, it turned out that the diffusion resistance on the cathode side is clearly dependent on the air flow rate and can be evaluated successfully by EIS. Generally, utilization of air is $30 \%-60 \%$ [49]. The 
condition of 0.520 NLPM, which corresponds to $40 \%$ utilization of air, thus is employed hereafter.

Influence of gas humidification temperature - The water management for the membrane is also important for proper cell performance. If an excessive amount of moisture is applied to a cell, the moisture would occupy the voids in GDL, leading to degradation of cell performance. This phenomenon is called "flooding". In moisture poor state, on the other hand, proton conductivity in membrane would be extinguished and this causes poor cell performance, what is called "dryout". These phenomena give a detrimental effect to cell performance [52,54]. Thus, the relationship between EIS and flooding or dryout which occurs within the membrane and GDL was investigated. Figure 5a shows cell voltage variation with the gas humidification temperature. As the gas humidification temperature increases, the resulting cell voltage becomes higher. The cell voltage was $0.56 \mathrm{~V}$ for the graphite bipolar plate employing cell and $0.54 \mathrm{~V}$ for the type 430 stainless steel one at $323 \mathrm{~K}$ and it was raised to $0.68 \mathrm{~V}$ for graphite bipolar plate employing cell and $0.63 \mathrm{~V}$ for type 430 stainless steel one at $353 \mathrm{~K}$. Figure $5 \mathrm{~b}$ shows the impedance spectra collected under different gas humidification temperatures. The arc as a whole shifted to the lower resistance direction in the real axis with increasing the temperature for both bipolar plates, maintaining the shapes. Figure 5c 
shows the calculated values of resistance from the equivalent circuit. With increasing the gas humidification temperature, however, the $R_{\mathrm{m}}$ and $R_{\mathrm{ct}}(\mathrm{C})$ values obviously decreased. The value of $R_{\mathrm{m}}$ was approximately $193 \mathrm{~m} \Omega \mathrm{cm}^{2}$ for graphite bipolar plate employing cell and $328 \mathrm{~m} \Omega \mathrm{cm}^{2}$ for type 430 stainless steel one at $323 \mathrm{~K}$ and it reached around $75 \mathrm{~m} \Omega \mathrm{cm}^{2}$ for graphite bipolar plate employing cell and $213 \mathrm{~m} \Omega \mathrm{cm}^{2}$ for type 430 stainless steel one at $353 \mathrm{~K}$. This is probably because the supplied moisture is filled in the membrane and this, in turn, improves the proton conductivity. The value of $R_{\mathrm{ct}}(\mathrm{C})$ was approximately $287.5 \mathrm{~m} \Omega \mathrm{cm}^{2}$ for graphite cell and $230 \mathrm{~m} \Omega \mathrm{cm}^{2}$ for type 430 stainless steel one at $323 \mathrm{~K}$ and it reached around $220 \mathrm{~m} \Omega \mathrm{cm}^{2}$ for graphite bipolar plate employing cell and $113 \mathrm{~m} \Omega \mathrm{cm}^{2}$ for type 430 stainless steel one at $353 \mathrm{~K}$. As mentioned above, this is because the $R_{\mathrm{ct}}(\mathrm{C})$ is correlative to the cell voltage. On the other hand, the $R_{\mathrm{d}}$ increased from $323 \mathrm{~K}$ to $353 \mathrm{~K}$. The value of $R_{\mathrm{d}}$ was approximately $88 \mathrm{~m} \Omega \mathrm{cm}^{2}$ for the graphite cell and $95 \mathrm{~m} \Omega \mathrm{cm}^{2}$ for the type 430 stainless steel one at $323 \mathrm{~K}$ and it reached around $123 \mathrm{~m} \Omega \mathrm{cm}^{2}$ for the graphite cell and $180 \mathrm{~m} \Omega \mathrm{cm}^{2}$ for the type 430 stainless steel one at $353 \mathrm{~K}$. It is most likely that the high $R_{\mathrm{m}}$ value at $323 \mathrm{~K}$ is caused by poor proton conductivity due to lack of moisture in membrane, whereas the high $R_{\mathrm{d}}$ value at $353 \mathrm{~K}$ is stemming from the water molecules stuck within GDL although they provide membrane with sufficient proton conductivity. It is possible to diagnose 
flooding or dryout phenomena by EIS giving affection to change in the $R_{\mathrm{d}}$.

Influence of corrosion on the stainless steel bipolar plates -From the practical

point of view, stainless steels are attracting wide attention as bipolar plate materials for PEMFCs [38-44]. Now, the urgent problem is corrosion of stainless steel in the PEMFC environment. EIS may allow one to diagnose the state of corrosion of stainless steel bipolar plates during operation of PEMFC. Corrosion products such as $\mathrm{Fe}^{2+}, \mathrm{Ni}^{2+}$ and $\mathrm{Cr}^{3+}$ may be released from the stainless steel bipolar plate and degrade cell performance, leading to an increase in some of the independence parameters $\left(R_{\mathrm{m}}, R_{\mathrm{ct}}(\mathrm{C})\right.$ and $\left.R_{\mathrm{d}}\right)$. To confirm the expected phenomena, we intentionally employed the type 430 stainless steel as a bipolar plate, which would be more readily corroded, compared with austenitic stainless steels, namely, acceleration test to make a corrosion state. Figure 6a shows cell voltage as a function of operation time. The initial voltage was approximately $0.67 \mathrm{~V}$ for graphite bipolar plate employing cell and $0.64 \mathrm{~V}$ for type 430 stainless steel one at $0.5 \mathrm{~A} \mathrm{~cm}^{-2}$ and it reached around $0.65 \mathrm{~V}$ for graphite bipolar plate employing cell and $0.58 \mathrm{~V}$ for type 430 stainless steel one after 336 hours.

At the same time, impedance was measured with the cell operation. The metal ion like $\mathrm{Fe}^{2+}$ released from the stainless steel bipolar plates can attack the membrane. Also, the $\mathrm{Fe}^{2+}$ can be oxidized to $\mathrm{Fe}^{3+}$ and it may subsequently accumulate as $\mathrm{Fe}(\mathrm{OH})_{3}$ 
in the hole of GDL. As a result, diffusion of the air in the cathode would be consequently obstructed by the deposited $\mathrm{Fe}(\mathrm{OH})_{3}$. This series of the process would results in the gradual deterioration of cell performance for the type 430 stainless steel cell shown in Fig. 6a. The resulting semicircles became larger for the type 430 stainless steel cell in Fig. 6b, especially those for the diffusion resistance $\left(R_{\mathrm{d}}\right)$ for the type 430 stainless steel employing cell. Meanwhile, there appears almost no change in the operation voltage and impedance spectra as well for the graphite employing cell in Fig. 6a and b. Similarly to the graphite cell, the type 430 stainless steel employing cell also exhibited almost no changes in the $R_{\mathrm{m}}$ and $R_{\mathrm{ct}}(\mathrm{C})$ ingredients in Fig. 6c. The value of $R_{\mathrm{m}}$ was approximately $105 \mathrm{~m} \Omega \mathrm{cm}^{2}$ for the graphite bipolar plate employing cell and 163 $\mathrm{m} \Omega \mathrm{cm}^{2}$ for the type 430 stainless steel one in the initial state and it reached around 103 $\mathrm{m} \Omega \mathrm{cm}^{2}$ for the graphite bipolar plate employing cell and $170 \mathrm{~m} \Omega \mathrm{cm}^{2}$ for the type 430 stainless steel one after 336 hours. The value of $R_{\mathrm{ct}}(\mathrm{C})$ was approximately $160 \mathrm{~m} \Omega \mathrm{cm}^{2}$ for the graphite bipolar plate employing cell and $180 \mathrm{~m} \Omega \mathrm{cm}^{2}$ for type 430 stainless steel one at the initial state. After 336 hours operation, the $R_{\mathrm{ct}}(\mathrm{C})$ value slightly increased for both cells. A striking feature for the cell is the gradual increase in the $R_{\mathrm{d}}$ component for the type 430 stainless steel bipolar plate employing cell in Fig. 6c, which agrees well with the progressive increase in the $R_{\mathrm{d}}$ arc in Fig. 6b. For example, the $R_{\mathrm{d}}$ 
values were $65 \mathrm{~m} \Omega \mathrm{cm}^{2}$ for the graphite bipolar plate employing cell and $113 \mathrm{~m} \Omega \mathrm{cm}^{2}$ for the type 430 stainless steel one before operation, and they became $80 \mathrm{~m} \Omega \mathrm{cm}^{2}$ for the graphite bipolar plate employing cell and $158 \mathrm{~m} \Omega \mathrm{cm}^{2}$ for the type 430 stainless steel one after 336 hours. The $R_{\mathrm{m}}$ is a parameter related to proton conductivity or contact resistance between bipolar plate and GDL, implying that metallic ions were incorporated into the membrane to lower the proton conductivity or deposited at the interface between GDL and bipolar plate to increase the ICR. The $R_{\mathrm{d}}$ is a parameter related to oxygen supply or drainage of the generated water. As shown in Fig.7, the type 430 stainless steel bipolar plates were severely corroded in both cathode and anode parts. This is a clear indicative that the movement of air or water could be delayed due to the sediment of the corrosion products on the surface of bipolar plate or in the hole of GDL, resulting in an increase of the $R_{\mathrm{d}}$. As a result, it is believed that the $R_{\mathrm{d}}$ component ascribed to the corrosion product on the surface of bipolar plates or in the hole of GDL can be monitored by the EIS method.

Figure 8 shows the atomic ratio of iron versus platinum in the MEA by XRF for type 430 stainless steel bipolar plate employing cell. The atomic ratio of iron versus platinum in the MEA was 0.002 for the fresh MEA. After 168 hours, however, it is surprising to note that the atomic ratio of iron versus platinum in the MEA increases to 
0.016 for the type 430 stainless steel bipolar plate employing cell. The atomic ratio of iron versus platinum in the MEA is almost constant from 168 hours to 336 hours. Note that corrosion of the bipolar plate occurs in the early state of cell operation. Again, considering that $R_{\mathrm{m}}$ is not increased, it is suggested that iron ion is not likely taken into membrane but deposited on the surface of bipolar plate by forming corrosion product such as iron (oxy)hydroxides or iron oxides.

In the present experiment, it is evident that the cell performance was degraded due to the corrosion of the stainless steel bipolar plates. The trouble in water drainage would be another cause to lead the higher resistance. In this experiment, it turned out that the $R_{\mathrm{d}}$ and corrosion of the stainless steel bipolar plate have correlation. Taking the above results into consideration, the corrosion situation of the stainless steel bipolar plates could be readily diagnosed by EIS measurement.

\section{Conclusions}

It is concluded that the condition of PEMFC operation can be diagnosed by EIS method. First, EIS was applied to the graphite and type 430 stainless steel bipolar plates employing cell as a function of current density, gas flow rates and gas humidification temperature. Moreover, an equivalent circuit was assumed and evaluated. As a result, 
the followings became clear. The resistance laid in series in the equivalent circuit, $R_{\mathrm{m}}$ typically increased due to degradation of membrane as appeared in a dry out state. It was obvious that cell voltage was more dependent on the $R_{\mathrm{ct}}(\mathrm{C})$. It was suggested that the $R_{\mathrm{d}}$ corresponds to diffusion resistance for oxygen supply and drainage of generated water in the cathode side.

Second, type 430 stainless steel bipolar plates employing cell was operated for 336 hours. The stainless steel bipolar plates were corroded both in anode and cathode sides and the corrosion progressed with operation time. At the same time, the effect of corrosion on the cell performance was evaluated by EIS method. It is clear that the value of $R_{\mathrm{m}}$ and $R_{\mathrm{ct}}(\mathrm{C})$ was almost constant. On the other hand, the value of $R_{\mathrm{d}}$ increased with progress of corrosion of the bipolar plates from 0 hour to 168 hours. Considering that $R_{\mathrm{m}}$ was not increasing, the corrosion of stainless steel bipolar plate is related to $R_{\mathrm{d}}$. Accordingly, EIS method is a useful tool to evaluate the cell performance in terms of corrosion of bipolar plates.

\section{Acknowledgements}

The authors thank Ms. Miwa Watanabe, Iwate University for her helpful assistance in the experimental work and Ube Industries, Ltd. and Mitsubishi plastics, Inc 
for their kind supply of gaskets. This research was partially supported by the Ministry of Education, Science, Sports and Culture, Grant-in-Aid for Scientific Research (c), $20560665,2008-2010$ 


\section{References}

[1] X. Yuan, H. Wang, Jian Colin Sun, J. Zhang, Int. J. Hydrogen Energy, 32 (2007) 4365.

[2] V. A. Paganin, C. L. F. Oliveira, E. A. Ticianelli, T. E. Springer, E. R. Gonzalez, Electrochim. Acta, 43 (1998) 3761.

[3] J.M. Song, S.Y. Cha and W.M. Lee, J. Power Sources, 94 (2001) 78.

[4] M. Schulze, N. Wagner, T. Kaz, K.A. Friedrich, Electrochim. Acta, 52 (2007) 2328.

[5] N. Wagner, T. Kaz, K.A. Friedrich, Electrochim. Acta, 53 (2008) 7475.

[6] E. Antolini, L. Giorgi, A. Pozio and E. Passalacqua, J Power Sources, 77 (1999) 136.

[7] Q. Guo, M. Cayetano, Y. Tsou, E.S. De-Castro and R.E. White, J Electrochem. Soc., 150 (2003) A1440.

[8] C.-M. Lai, J.-C. Lin, F.-P. Ting, S.-D. Chyou and Kan-Lin Hsueh, Int. J. Hydrogen Energy, 33 (2008) 4132.

[9] T.J. P. Freire, Ernesto R. Gonzalez, J. Electroanal. Chem., 503 (2001) 57.

[10] F.N. Büchi and G.G. Scherer, J. Electrochem. Soc., 148 (2001) A183.

[11] D.M. Bernardi and M.W. Verbrugge, J Electrochem. Soc., 139 (1992) 2477.

[12] M.S. Wilson, J.A. Valerio and S. Gottesfeld, Electrochim. Acta, 40 (1995) 355.

[13] T.E. Springer, T.A. Zawodzinski, M.S. Wilson and S. Gottesfeld, J. Electrochem. 
Soc., 143 (1996) 587.

[14] A. Fisher, J. Jindra and H. Wendt, J.Appl. Electrochem., 28 (1998) 277.

[15] L.R. Jordan, A.K. Shukla, R. Behrsing, N.R. Avery, B.C. Muddle and M. Forsyth, J. Power Sources, 86 (2000) 250.

[16] E. Passalacqua, G. Squadrito, F. Lufrano, A. Patti and L. Giorgi, J. Appl. Electrochem., 31 (2001) 449.

[17] C.-S. Kong, D.-Y. Kim, H.-K. Lee, Y.-G. Shul, T.-H. Lee, J. Power Sources, 108 (2002) 185.

[18] R.P. Ramasamy, E.C. Kumbur, M.M. Mench, W. Liu, D. Moore and M. Murthy, Int. J. Hydrogen Energy, 33 (2008) 3351.

[19] G. Chen, H. Zhang, H. Ma and H. Zhong, Int. J. Hydrogen Energy, 34 (2009) 8185.

[20] S. Slade, S.A. Campbell, T.R. Ralph and F.C. Walsh, J. Electrochem. Soc., 149 (2002) A1556.

[21] F. Damay and L.C. Klein, Solid State Ionics, 162-163 (2003) 261.

[22] B. Andreaus, G.G. Scherer, Solid State Ionics, 168 (2004) 311.

[23] R. Halseid, P.J.S. Vie and R. Tunold, J. Electrochem. Soc., 151 (2004) A381.

[24] M. Ciureanu, J. Appl. Electrochem., 34 (2004) 705.

[25] R.F. Suva, M. De-Francesco and A. Pozio, J. Power Sources 134 (2004) 18. 
[26] D.J.L. Brett, S. Atkins, N.P. Brandon, N. Vasileiadis, V. Vesovic, A.R. Kucernak, J. Power Sources 172 (2007) 2.

[27] G. Li and P.G. Pickup, J. Electrochem. Soc., 150 (2003) C745.

[28] M. Ciureanu and M. Badita, J. New Mater. Electrochem. Syst., 6 (2003) 163.

[29] T. Abe, H. Shima, K. Watanabe and Y. Ito, J. Electrochem. Soc., 151 (2004) A101.

[30] H.Xu, H. R. Kunz and J.M. Fenton, Electrochim. Acta, 52 (2007) 3525.

[31] N. Wagner, J. Appl. Electrochem., 32 (2002) 859.

[32] J.P. Diard, N. Glandut, B. Le-Gorrec and C. Montella, J. Electrochem. Soc., 151 (2004) A2193.

[33] X.Z. Yuan, J.C. Sun, M. Blanco, H. Wang, J. Zhang and D.P. Wilkinson, J. Power Sources, 161 (2006) 920.

[34] X.Z. Yuan, J.C. Sun, M. Blanco, H. Wang, J. Zhang and D.P. Wilkinson, J. Power Sources, 161 (2006) 929.

[35] X. Yan, M. Hou, L. Sun, D. Liang, Q. Shen, H. Xu, P. Ming and B. Yi, Int. J. Hydrogen Energy, 32 (2007) 4358.

[36] W. H. Zhu, R.U. Payne and B.J. Tatarchuk, J. Power Sources, 168 (2007) 211.

[37] E.A. Cho, U.-S. Jeon, H.Y. Ha, S.-A. Hong, I.-H. Oh, J. Power Sources, 125 (2004) 178 . 
[38] P.L. Hentall, J.B. Lakeman, G.O.Mepsted, P.L.Adcock, J.M.Moore, J. Power Sources, 80 (1999) 235 .

[39] D.P. Davies, P.L. Adocock, M. Turpin, S.J. Rowen, J. Appl. Electrochem. 30 (2000) 101.

[40] J. Wind, R. Spah,W. Kaiser, G. Bohm, J. Power Sources, 105 (2002) 256.

[41] H. Yashiro, R. Asaishi, S. Kuwata, M. Kumagai, A. Yao, Trans. Mater. Res. Soc. Jpn., 32 (2007) 963.

[42] H.Wang, J.A. Turner, J. Power Sources, 180 (2008) 791.

[43] M. Kumagai, S.-T. Myung, S. Kuwata, R. Asaishi, H. Yashiro, Electrochim. Acta, $53(2008) 4205$.

[44] M. Kumagai, S.-T. Myung, R. Asaishi, Y. Katada, H. Yashiro, J. Power Sources, 185 (2008) 815.

[45] M. Kumagai, S.-T. Myung, S. Kuwata, R. Asaishi, Y. Katada, H. Yashiro, Electrochim. Acta, 54 (2009) 1127.

[46] A. Pozio, R. F. Silva, M. De Francesco, and L. Girgi, Electrochim. Acta, 48 (2003) 1543.

[47] H.Wang, J.A. Turner, J. Power Sources, 183 (2008) 576.

[48] Y. Ishibashi, A. Nishikata, and T. Tsuru, ECS Trans. 16 (2009) 85. 
[49] Japan Automobile Research Institute, NEDO report (12-17-013-2-0002-2) p. 21

(2001).

[50] N. Wagner, Electrochemical power sources-fuel cells, in: E. Barsoukov, J.R. Macdonald (Eds.), Impedance Spectroscopy: Theory, Experiment, and Applications, second ed., John Wiley \& Sons Inc., p. 497 (2005).

[51] M. Ciureaun, R. Roberge, J. Phys. Chem. B, 105 3(2001) 531.

[52] S.D. Knights, K.M. Colbow, J. St-Pierre, D.P. Wilkinson, J. Power Sources, 127 (2004) 127.

[53] S.-T. Myung, M. Kumagai, R. Asaishi, Y.-K. Sun, H. Yashiro, Electrochem. Commun., 10, 480 (2008).

[54] N.Fouquent, C.Doulet, C.Nouillant, G.Dauphin-Tanguy, B.Ould-Bouamamn, J. Power Souruces, 159 (2006) 905. 


\section{Figure captions}

Figure 1. The equivalent circuit of the PEMFC (a) and an illustration of data fitting (b).

Figure 2. Influence of applied current density: cell voltage (a), impedance cole-cole plots (b) and impedance parameters (c).

Figure 3. Influence of hydrogen flow rate: cell voltage (a), impedance cole-cole plots (b) and impedance parameters (c).

Figure 4. Influence of air flow rate: cell voltage (a), impedance cole-cole plots (b) and impedance parameters (c).

Figure 5. Influence of gas humidification temperature: cell voltage (a), impedance cole-cole plots (b) and impedance parameters (c).

Figure 6. Influence of corrosion progress on type 430 stainless steel bipolar plates: time variation of cell voltage (a), cole-cole plots (b) and impedance parameters (c).

Figure 7. Metallurgical microscopic images of the rib surfaces for type 430 stainless steel bipolar plates. (a) anode side after 168 hour, (b) cathode side after 168 hour, (c) anode side after 336 hour, (d) cathode side after 336 hour. The scale bar indicates $1 \mathrm{~mm}$.

Figure 8. XRF analysis of Fe/Pt atomic ratio in the MEA with operation time. Analyzed 
area was $78.50 \mathrm{~mm}^{2}$.

Page 25 of 34 
Table 1. Chemical composition of the stainless steels (mass \%).

\begin{tabular}{cccccc}
\hline & $\mathrm{C}$ & $\mathrm{Si}$ & $\mathrm{Mn}$ & $\mathrm{Cr}$ & $\mathrm{Fe}$ \\
\hline Type 430 & 0.036 & 0.23 & 0.60 & 16.15 & Bal. \\
\hline
\end{tabular}




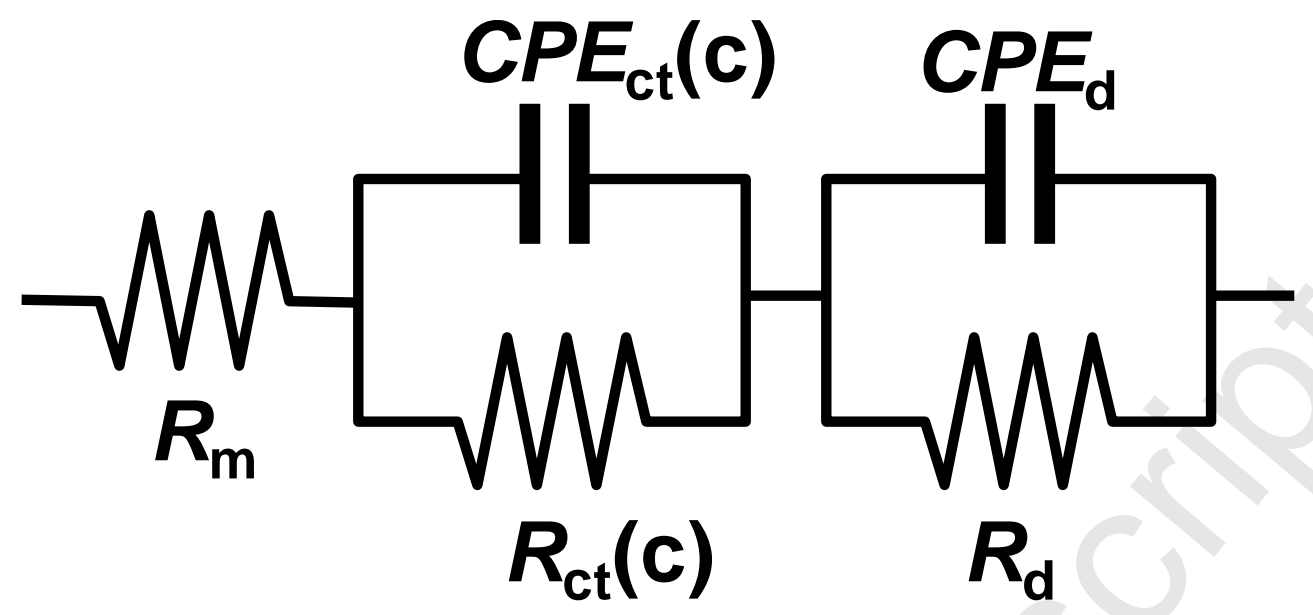

Figure 1. 

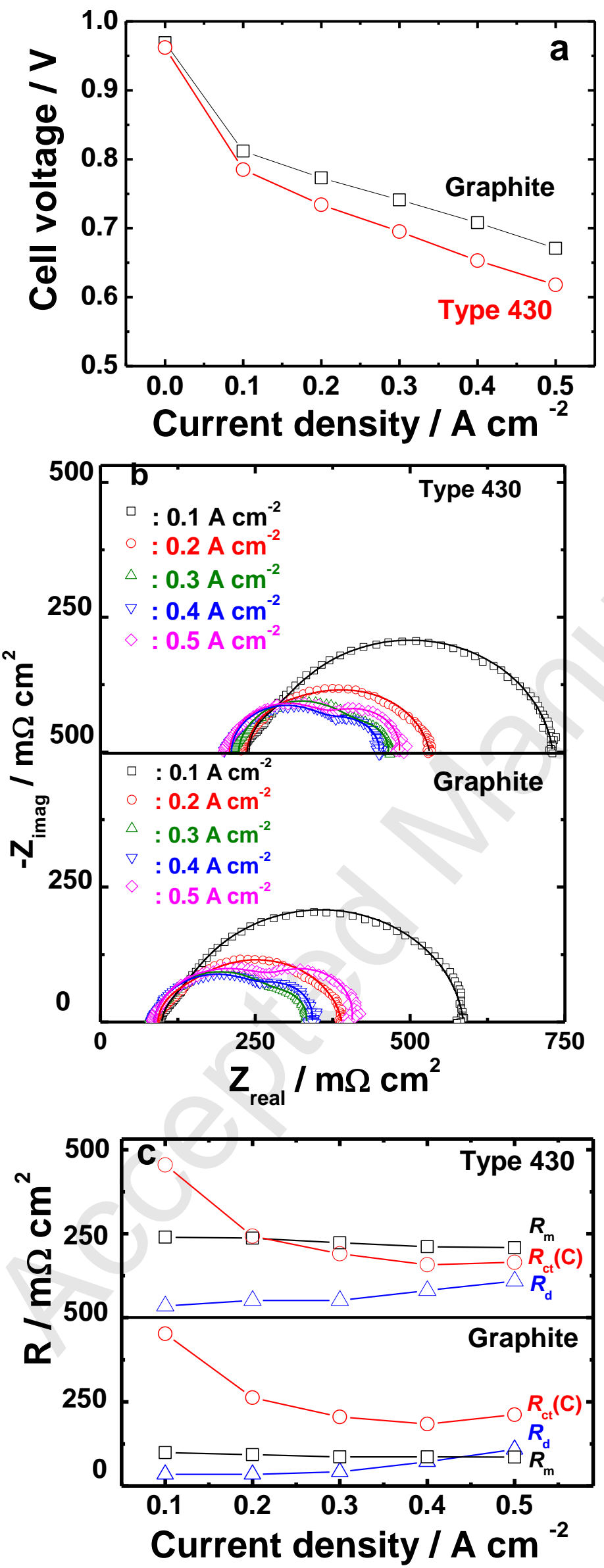

Figure 2. 


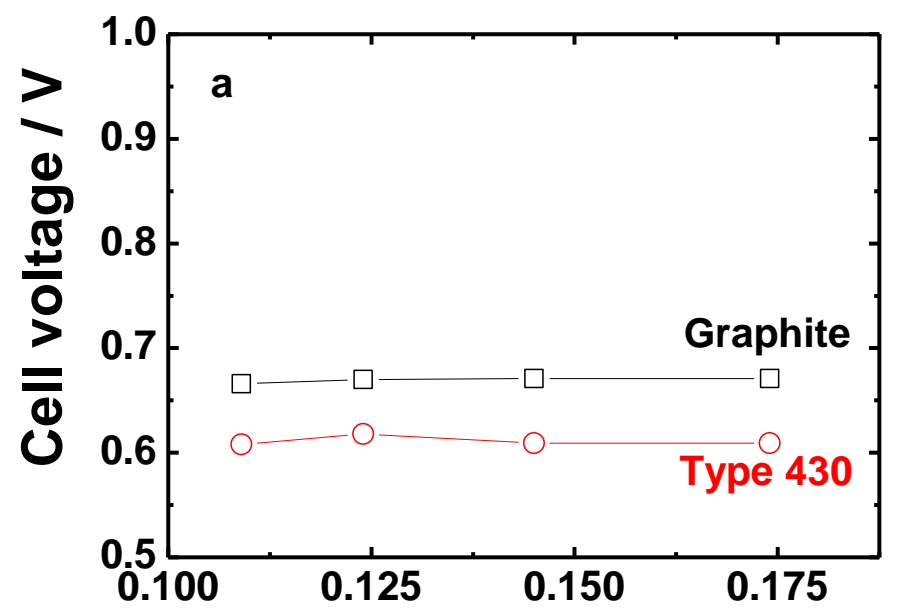

Flow rate of hydrogen / NLPM
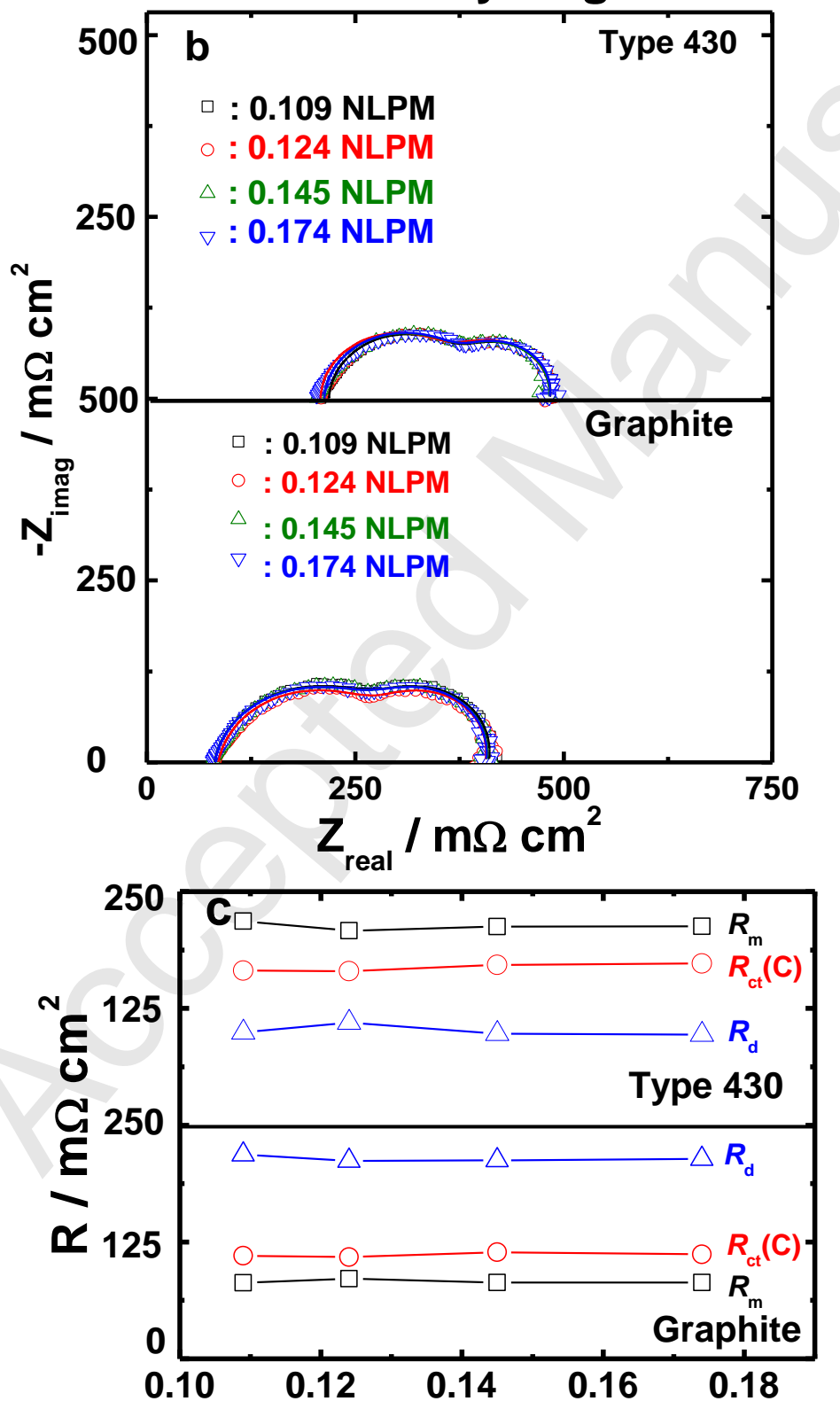

Figure 3.

Flow rate of hydrogen / NLPM 


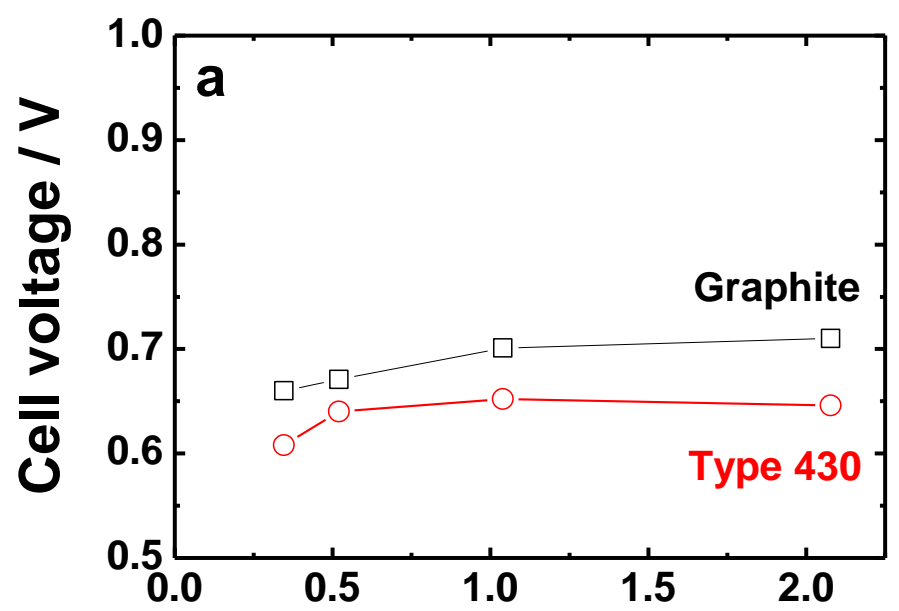

Flow rate of air / NLPM
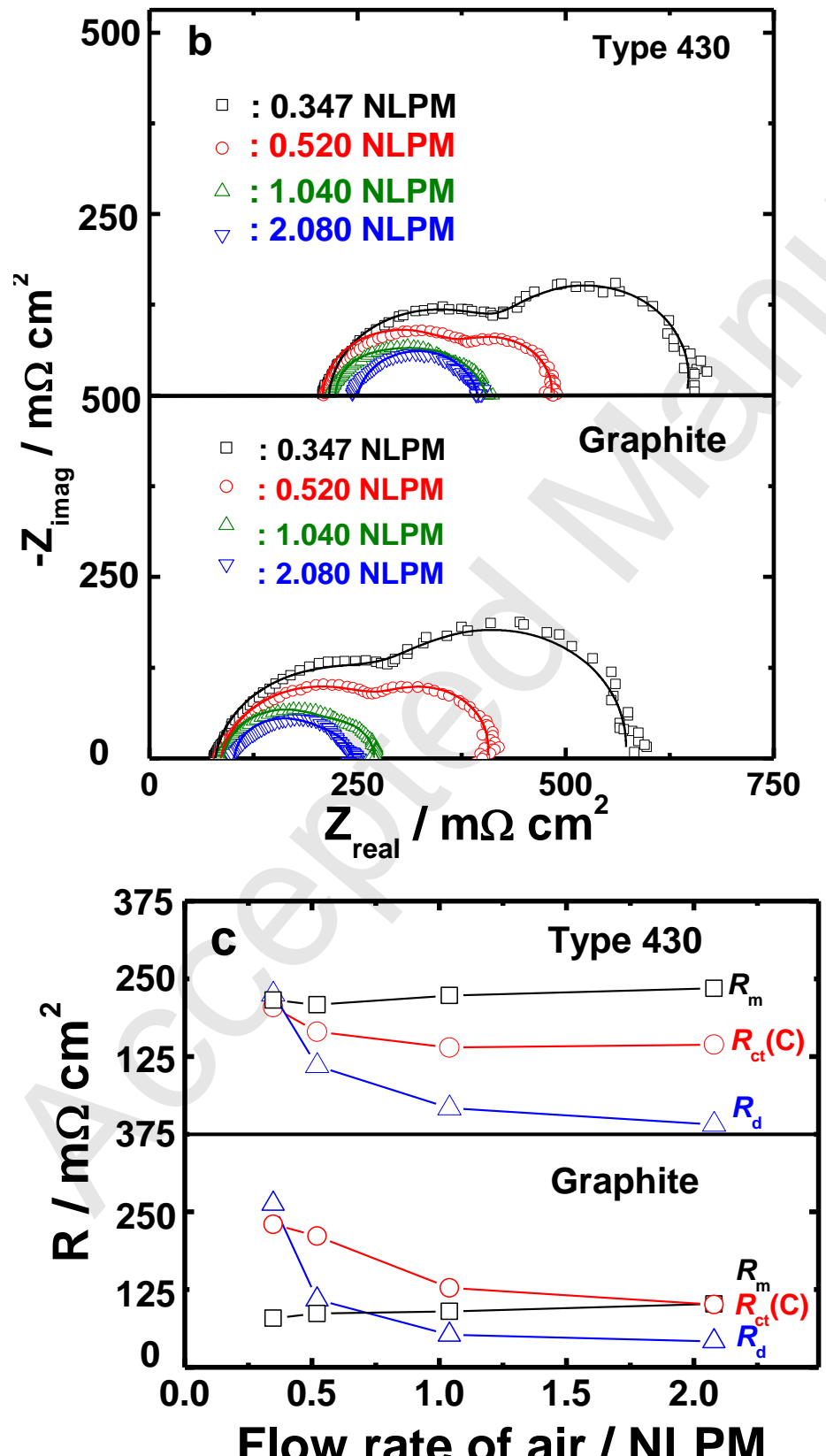

Figure 4. 


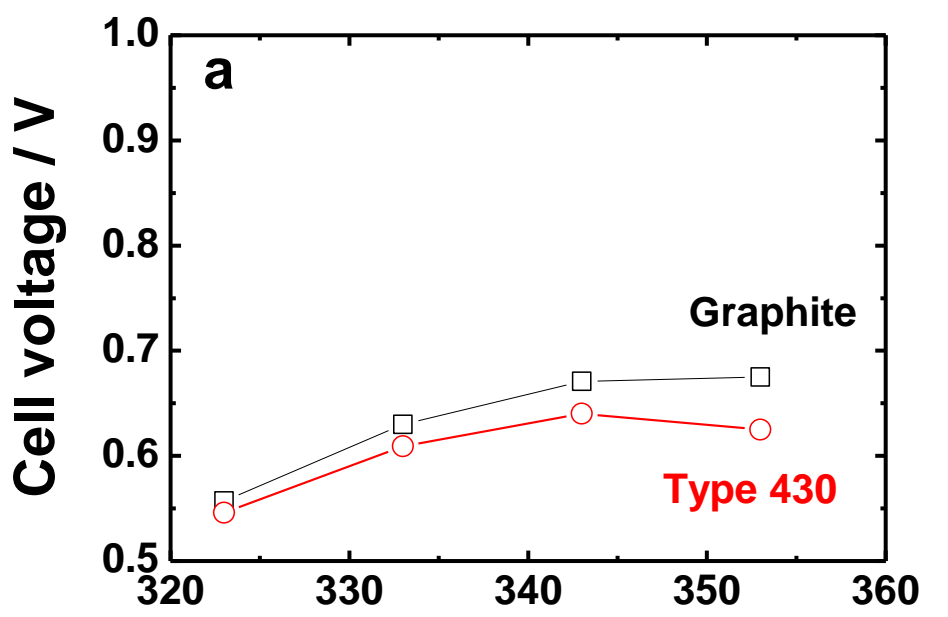

Gas humidification temperature / K
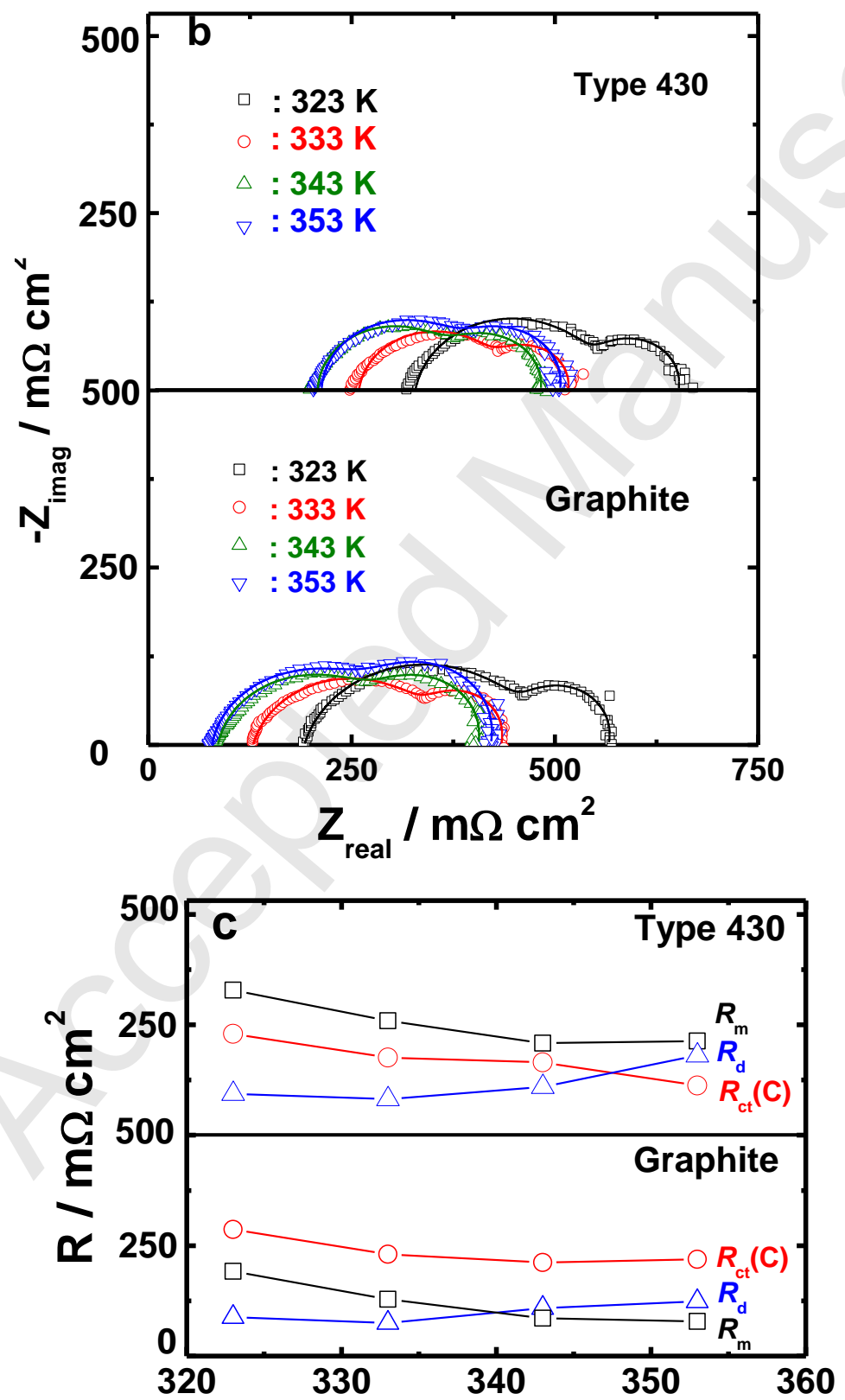

Figure 5.

Gas humidification temperature / K 

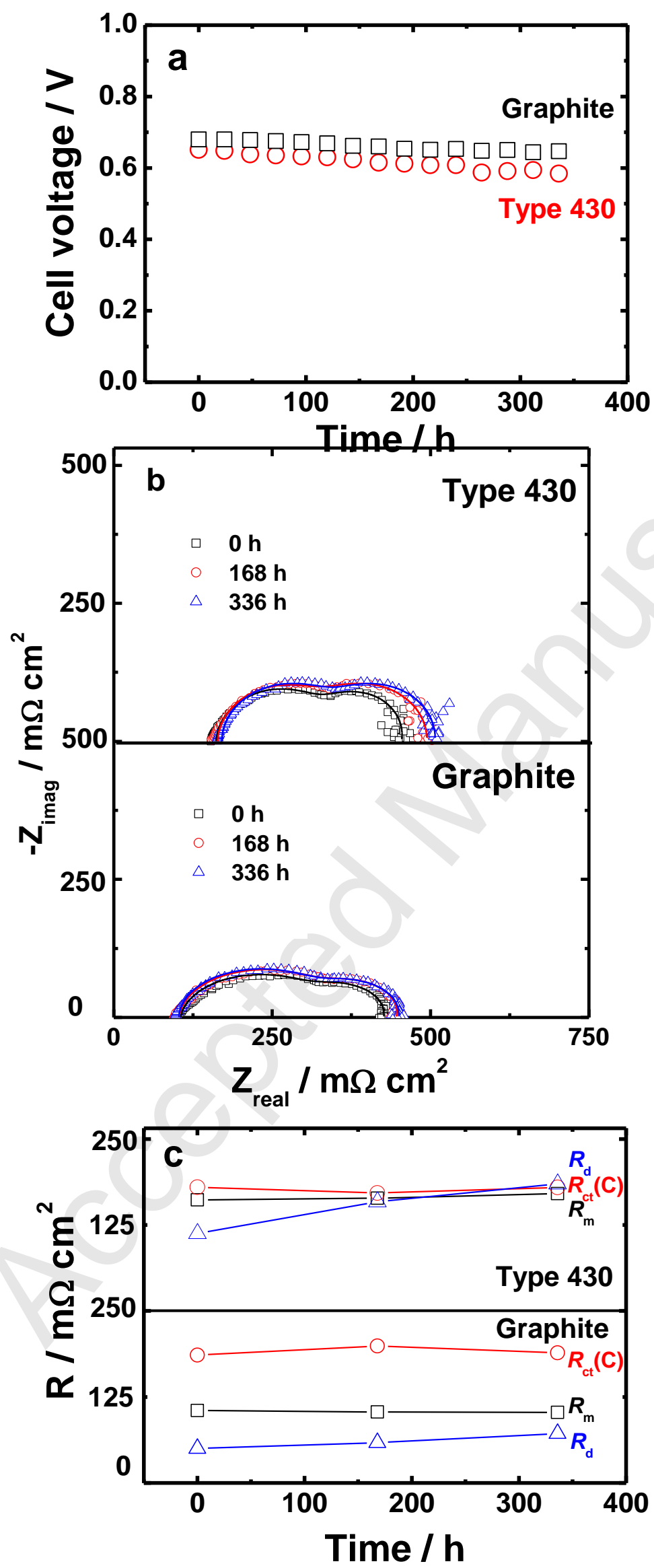

Figure 6. 


\section{Anode}
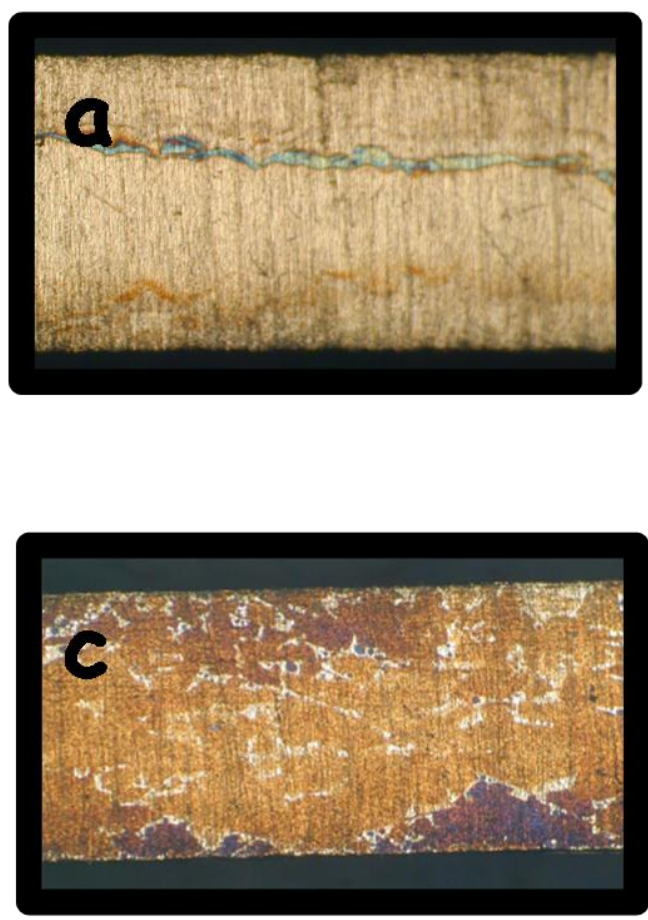

Figure 7.

\section{Cathode}
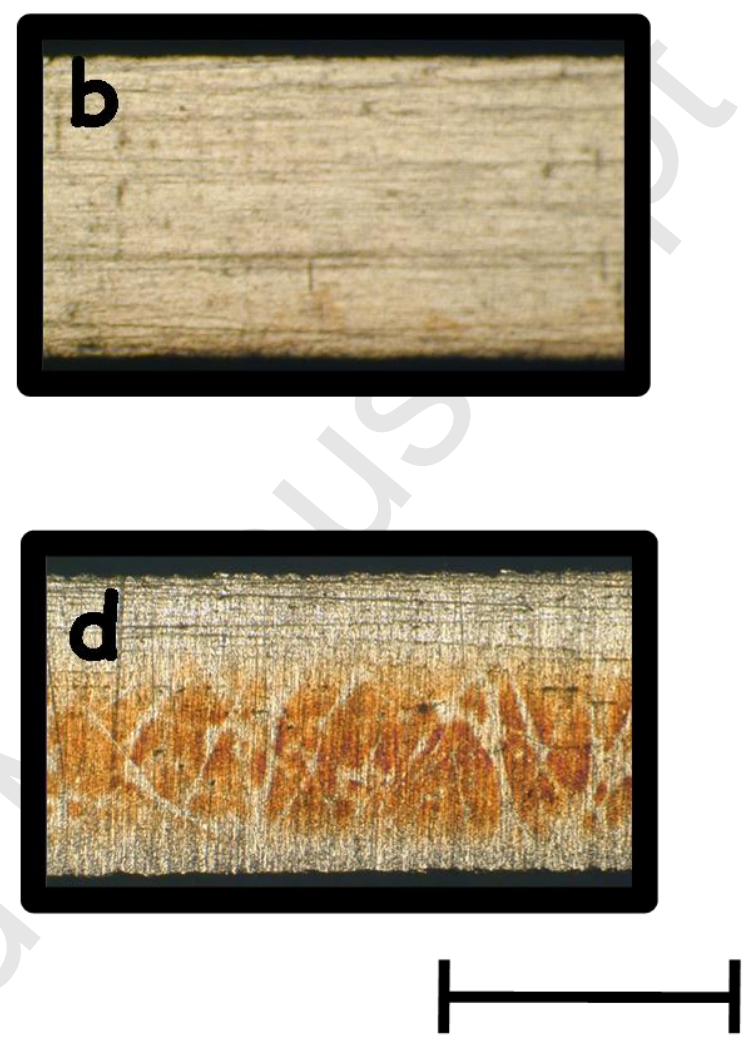

$1 \mathrm{~mm}$ 


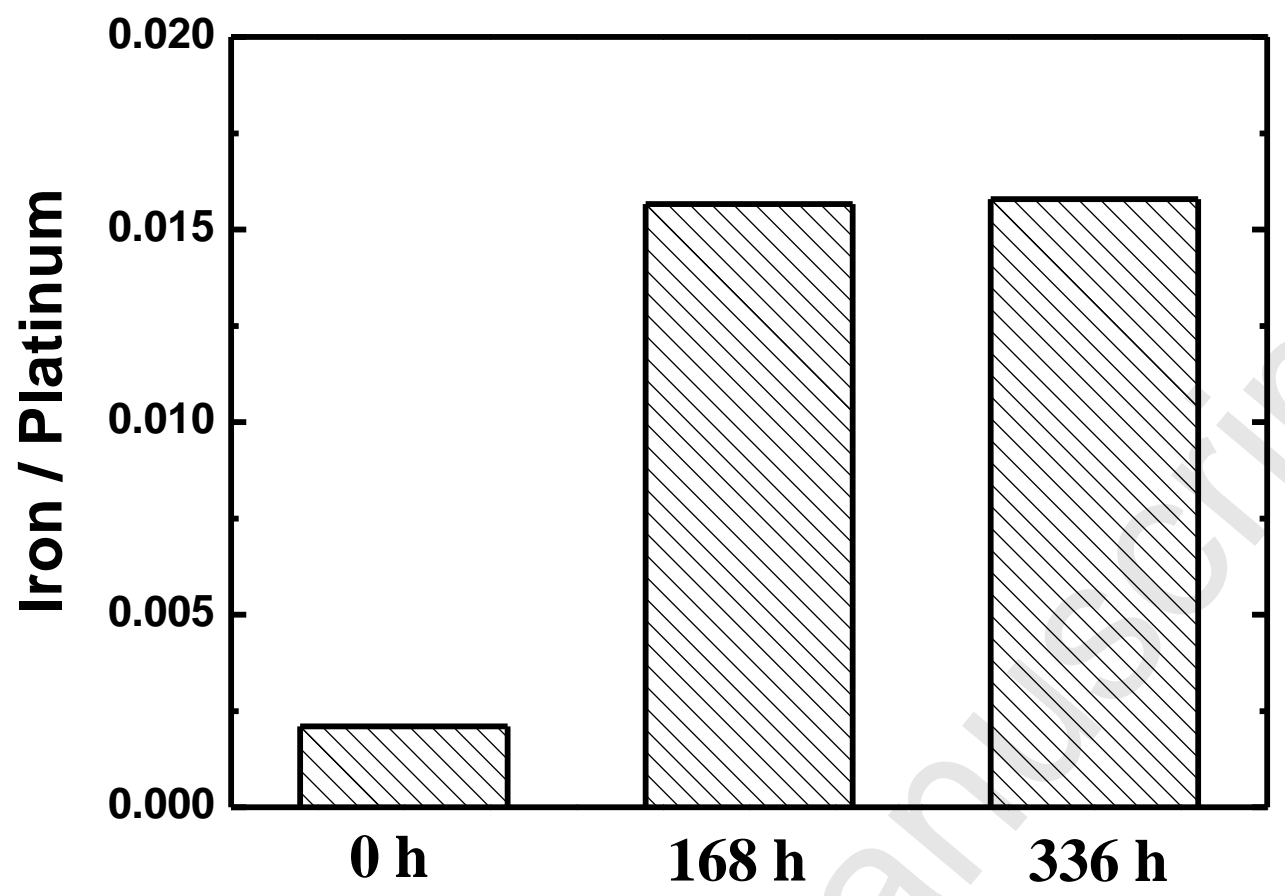

Figure 8. 